ARTUR MAJER

Państwowa Wyższa Szkoła Filmowa, Telewizyjna i Teatralna im. Leona Schillera w Łodzi

\section{Narracja czasem. Analiza struktury narracyjnej filmu Arrival (2016) Denisa Villeneuve'a}

\begin{abstract}
Majer Artur, Narracja czasem. Analiza struktury narracyjnej filmu Arrival (2016) Denisa Villeneuve'a [Narrative by time. The Analysis of narrative structure in Denis Villeneuve's Arrival (2016)]. "Images" vol. XXVIII, no. 37. Poznań 2020. Adam Mickiewicz University Press. Pp. 221-232. ISSN 1731-450X. DOI 10.14746/i.2020.37.13.

The article deals with the narrative structure of Denis Villeneuve's Arrival. Using the concept of a skeptical viewer as a starting point, the author follows the processes of unveiling meanings, both when it comes to the understanding of the plot of the story, as well as the senses and morals stemming out of it. The viewer's activity appears to be engaged with the activity of a character who is determined to discover the generic science fiction mystery, i.e. to learn the secret of the aliens' language. The language, in turn, leads to revealing the time reliances in the film, as well as to formulating the thesis on a specific kind of storytelling: not as a "narrative about time," but rather a "narrative by time."
\end{abstract}

KeYworDs: film narration, Arrival, Denis Villeneuve, skeptical viewer, trusting spectator, story structure, narrative structure

Przedmiotem mojego badania jest film Arrival z 2016 roku w reżyserii Denisa Villeneuve’a według scenariusza Erica Heisserera na podstawie opowiadania Teda Chianga zatytułowanego Story of Your Life. Świadomie używam oryginalnych angielskich tytułów. O ile bowiem polski tłumacz literatury (Michał Jakuszewski) przełożył tytuł dosłownie jako Historię twojego życia, o tyle decyzją dystrybutora (UIP) film w kinach w Polsce wyświetlany był jako Nowy początek. Skoro zaś mamy do czynienia z gatunkiem science fiction, sugestia „przybycia” (arrival) Obcych zasadniczo różni się od „nowego początku”. W pierwszym przypadku podkreślana jest tajemnica i niepewność wynikająca z kontaktu z Obcymi, w drugim poniekąd odkrywa się jej rąbek, dając do zrozumienia, że Obcy spowodują jakiś nowy rozdział, nową rzeczywistość. Już jednak sama rezygnacja z tytułu opowiadania pozwalała twórcom filmu skierować uwagę widza właśnie na gatunek fantastyki naukowej, ku jego konwencjom i tematom, a odciągać ją od tajemniczego adresata wskazywanego tytułem literackiego pierwowzoru. Ten zabieg ma znamiona działań narracyjnych, których przecież główną funkcją jest kierowanie aktywnością widza podczas lektury dzieła. Jako że moje zainteresowania skupią się właśnie na strukturze narracyjnej filmu Arrival, z premedytacją pominę kontekst opowiadania Chianga. Powrócę do omówienia go na końcu artykułu, w swoistym epilogu moich rozważań. Obraz Villeneuve’a jest dość
Images vol. XXVIII/no. 37

Poznań 2020

ISSN 1731-450x
Kilka słów o metodzie i przedmiocie 
wierną jego adaptacją, lecz twórca filmowy inaczej przekazuje te same w zasadzie wnioski. Inaczej opowiada (narratywizuje) podobną treść (fabułę).

Z wielu sposobów analizy narracji dzieła filmowego zawsze najbardziej atrakcyjne, bo odwołujące się do doświadczeń odbiorcy (czyli też samego analityka), jest podążanie ścieżką aktywności widza w konstruowaniu znaczeń. Nie wynikają one bowiem tylko z tego, o czym traktuje dany film, lecz - może nawet przede wszystkim - z tego, jak jego treść została przedstawiona; a zatem z narracji właśnie. Ma ona zapewnić odbiorcy przyjemność odkrywania zagadki, zapełniania luk fabuły, dodatkowego tłumaczenia motywacji, logicznego łączenia wydarzeń. Słowem: narracja apeluje do ludzkiego pragnienia poznania prawdy[1]. Do nieustannego zadawania pytań typu: kto jest za to odpowiedzialny? co z tego wynika? jak to się stało? dlaczego to się wydarza? - i tak dalej... Konsument utworów narracyjnych znajduje na nie odpowiedzi w trakcie lektury, czasami nawet nieświadomie. Jak one będą brzmieć, jaką zapewnią mu przyjemność, nie zależy jednak tylko od narracji, lecz także od jego osobistych uwarunkowań: kompetencji społecznych, wiedzy, inteligencji, dobrej woli. W tym kontekście pomocne okazuje się rozróżnienie widza ufnego i sceptycznego, których figury wykorzystał - opierając się na ustaleniach Umberto Eco i Davida Bordwella - Jacek Ostaszewski w swojej analizie narracji Podejrzanych Briana Singera[2].

O ile pierwszy typ widza bagatelizuje luki fabularne w logice opowieści, drugi kwestionuje je, piętnuje i wątpi w ich łatwe, oczywiste wypełnienia sugerowane przez narrację utworu. A zatem dokonuje swoistej analizy tej narracji, zastępując powyższe - dodajmy: proste, podstawowe - pytania bardziej złożonymi, na przykład: co mam o tym myśleć? jak to rozumieć? czemu to służy? - a może nawet: do czego próbuje mnie przekonać nadawca? Analitykowi filmu bliższa jest, rzecz jasna, ta właśnie postawa. Wydaje się zarazem, że biorąc pod uwagę utwór filmowy, będący adaptacją innego dzieła narracyjnego, możemy mówić o jeszcze jednej odmianie widza, a mianowicie o widzu metaświadomym[3]. Nierzadko bowiem adaptacje podążają linią fabularną i narracyjną pierwowzoru. Jego uprzednia lektura odziera zatem odbiór filmu z tajemnicy. Ale też pozwala w naturalny sposób zbliżyć się do postawy sceptycznej. Do kategorii widza metaświadomego również powrócę w epilogu. Ścieżka widza sceptycznego przydaje się bowiem dużo bardziej, gdy chcemy odkryć sposób konstruowania narracji i znaczeń samego filmu, funkcjonującego wszak także w oderwaniu od literackiego pierwowzoru.

[1] Por. J. Culler, Teoria literatury. Bardzo krótkie wprowadzenie, tłum. M. Bassaj, Warszawa 1998, s. 109. [2] J. Ostaszewski, Podejrzani Briana Singera. Przypadek kłamstwa narracyjnego, „Kwartalnik Filmowy” 2004, $\mathrm{nr} 46$, s. 26-42.
[3] Czyli świadomym istnienia pierwowzoru, wobec którego film jest adaptacją, będąc jego transpozycją, transformacją, bądź jak ujmuje to Alicja Helman „twórczą zdradą,. Por. A. Helman, Twórcza zdrada. Filmowe adaptacje literatury, Poznań 1998, s. 7-18. 
Film rozpoczyna jednak narracja zupełnie zaskakująca, bliska jak się okaże - właśnie tytułowi opowiadania Chianga. W serii ujęć i scen widzimy matkę z dzieckiem. Początkowo jest to osesek i niemowlę, potem mała dziewczynka. Cykl tych scen (pojedynczych ujęć) wyznacza jej dorastanie: bawi się z matką przebrana w kowbojkę, jako dziecko zasypiające w poczuciu bezpieczeństwa mówi do matki: „kocham cię”, by za chwilę jako dorastająca młoda kobieta krzyczeć: „nienawidzę cię". W następnych mikroscenach widać szpital, rozpacz matki sugerującą nieuleczalną chorobę dziecka, a w końcu śmierć dziewczyny i słowa rodzicielki: „wróć do mnie”. Sekwencji tej towarzyszy nieustanna narracja z offu matki, dotycząca życia córki i kierowana właśnie do niej (Historia twojego życia). Kończy się ona znaczącym obrazem: przejściem bohaterki z korytarza szpitalnego na korytarz uczelni i słowami wypowiedzianymi być może wciąż do nieżyjącej, lecz zarazem po prostu będącymi gorzką refleksją pogrążonej w żałobie kobiety: „Teraz niezbyt już wierzę w zakończenia i początki. Są dni, które definiują twoje życie. Jak dzień, w którym oni przybyli”. Ta chwila jest jednocześnie zapowiedzią gatunkowego ustanowienia akcji: przybycia Obcych. W tym właśnie miejscu zaczyna się opowieść gatunku science fiction.

Pozwoliłem sobie opisać tę początkową sekwencję tak dokładnie, uznając za wspomnianym Jackiem Ostaszewskim, że „sceny otwierające pełnią kluczową rolę w umiejscawianiu przez widzów akcji, określeniu przynależności gatunkowej, budowaniu oczekiwań i stawianiu hipotez co do dalszego rozwoju akcji. Początek filmu ujawnia też, jak twórcy filmu wykorzystują konwencje stylistyczne (sposób kadrowania, montaż, dźwięk) jako nośnik informacji narracyjnej”[4]. Widz z sekwencji początkowych scen filmu Arrival przede wszystkim dowiaduje się o sytuacji życiowej głównej bohaterki, Louise Banks (Amy Adams). Rozpoznaje ją jako matkę, która straciła dziecko. Aż do sekwencji finałowej każde wspomnienie córki, Hannah, będzie działało (może działać) jako potwierdzenie tej hipotezy.

Sceptyczna postawa odbiorcza każe w nią zwątpić nieco wcześniej, do czego przede wszystkim zachęca zmiana na rzeczonym poziomie stylistycznym. Obrazy matki i dziecka są początkowo raczej dynamiczne, a refleksję, zadumę, atmosferę żałoby wprowadza głos kobiety komentujący - jak się wydaje - wydarzenia przeszłe. Tymczasem, gdy wraz z Louise wkraczamy na uczelnię, narracja z offu kończy się, zaś tryb przedstawiania rzeczywistości w zauważalny sposób się zmienia: kadry są symetryczne, ruchy kamery i montaż spowolnione. W niemal całym filmie właśnie tak toczy się opowieść. Dynamika powracać będzie tylko podczas wspomnień o dziecku. Widz naiwny potraktuje ten fakt jako kolejną motywację psychologiczną: Louise przeżywa stratę. $Z$ rezerwą postrzegając zmianę sposobu filmowania, należałoby jednak powrócić do słów bohaterki: powiedziała, że teraz nie wierzy w zakończenia i początki, oraz że jednym z dni definiujących życie 
był ten, gdy przybyli Obcy. Czyżby sugerowała, że żałoba po utracie córki tego dnia się dla niej skończyła? Że inne działania (na przykład próba rozwikłania zagadkowego przybycia) całkowicie ją odmieniły? To wszystko tylko hipotezy dla zbyt oczywistego tłumaczenia świata psychologią postaci ogniskującej wydarzenia. Warto przy okazji zwrócić uwagę na słowo „teraz” oraz zastosowany w tej wypowiedzi czas przeszły. Czy jest to po prostu retoryka, czy może implikacja przenikania się teraźniejszości (przekonań: „teraz niezbyt już wierzę...”) z przeszłością (akcji: „...dzień, w którym oni przybyli”)? Na tym poziomie lektury nie sposób oczywiście uzyskać odpowiedzi. Ważne staje się jedynie punktowanie wątpliwości i niepewności po to, by móc je w trakcie tej lektury weryfikować.

\section{Rozwinięcie}

Tymczasem od wybrzmienia analizowanych wyżej słów do zasadniczego zwrotu akcji, w którym bohaterka zdaje sobie sprawę ze swoich nowych umiejętności lingwistycznych i tym samym odkrywa sposób na rozwiązanie zagadki fabularnej, mija 80\% filmu[5]. Cały ten czas poświęcony zostaje na realizowanie przez pierwszo- i drugoplanowe postaci postawionych przed nimi celów. Ich aktywność (lub niepodjęcie jej) prowadzić ma do rezultatu (albo też jego braku), jak w triadzie funkcyjnej opracowanej przez Łukasza Plesnara w jego klasycznej już analizie struktury fabularnej Obywatela Kane’a Orsona Wellesa (cel $\rightarrow$ aktywność/brak $\rightarrow$ rezultat/brak). Plesnar powoływał się na pojęcia funkcji (postaci w fabule) Wladimira Proppa i schematu sekwencyjnego Claude'a Bremonda. Jego triady funkcyjne pokazują, jak działania bohaterów prowadzą do próby realizacji postawionych przed nimi zadań[6]. Choć zasadniczo służą opisowi struktur fabuły lub schematów fabularnych[7], ufam, że pozwolą także odtworzyć schematy narracji prowadzącej widza do konstruowania znaczeń wynikających z lektury dzieła. By jednak przejść do takich analiz, niezbędne jest nakreślenie przebiegu głównego wątku fabularnego.

Przybycie Obcych na Ziemię sprawia, że rządy państw na całym świecie angażują zespoły naukowców do pracy nad próbą zrozumienia natury i przyczyny kontaktu. Jedną z nich jest główna bohaterka filmu, dr Louise Banks, lingwistka niegdyś już pracująca dla rządu amerykańskiego, a więc posiadająca odpowiednie uprawnienia. Jej współpracownikiem zostaje fizyk Ian Donnelly (Jeremy Renner). Ich główny cel jest eksplicytnie sformułowany przez przełożonego, pułkownika Webera (Forrest Whitaker), a także wielokrotnie powtarzany

[5] Film trwa 116 minut, zaś opisywany w tym miejscu segment związany z zasadniczym działaniem bohaterów trwa od ok. 4 minuty do ok. 90 minuty. [6] Ł. Plesnar, Organizacja struktury fabularnej Obywatela Kane Orsona Wellesa, [w:] Analizy i interpretacje. Film zagraniczny, red. A. Helman, Katowice 1986, s. $54-57$.
[7] Plesnar definiuje strukturę fabularną jako immanentny składnik utworu (nie może istnieć poza nim), lecz możliwy do odkrycia dzięki zabiegom narracyjnym; jest to warstwa przedstawiona zawdzięczająca swe istnienie warstwie przedstawiającej. Schemat fabularny to struktura fabularna tak, jak jest ona przedstawiona w dziele, zaś fabuła to jej rekonstrukcja chronologiczna. Por. ibidem, s. 44-45. 
przez samych badaczy: uzyskanie od Obcych odpowiedzi na pytanie „What is your purpose on Earth?” (Jaki jest wasz cel na Ziemi? Po co tu przybyliście?). Dokonuje się tym samym dramaturgiczne zawiązanie akcji, a celem pierwszej triady funkcyjnej jest rozpoznanie przyczyn przybycia Obcych zwanych heptapodami. Z tym wątkiem fabularnym związane są też inne cele pośrednie. Jako że przybycie Obcych spowodowało destabilizacje społeczeństw w zasadzie na całym globie oraz zaostrzyło polityczne napięcia, odpowiedź na powyższe pytanie ma też załagodzić te problemy. Ostatecznie chodzi zatem o to, by działania, które mają podjąć bohaterowie, prowadziły poprzez kontakt i interakcję do wzajemnego porozumienia i zrozumienia, być może także wymiany z Obcymi (jest mowa o zaawansowanej technice, którą heptapody mogą znać i chcieć się nią podzielić). Przypomina to podstawowe cele komunikacji[8], z czego oczywiście zdaje sobie sprawę para głównych bohaterów (oraz ich współpracownicy naukowcy na całym świecie), lecz co pozostaje całkowicie nieistotne dla wojsk i rządów. Najważniejsze jednak, że tak postawiony cel główny ostatecznie konstytuuje gatunek science fiction jako konwencję opowieści. Już wszak Susan Sontag w latach sześćdziesiątych XX wieku pisała (choć w odniesieniu do „katastroficznego” sf prezentującego inwazję Obcych), że w tego typu filmach uratowanie świata jest celem nadrzędnym bohatera, który działa w trudzie niezrozumienia czy bagatelizowania problemu przez innych[9]. To będzie również udziałem Louise oraz wspierającego ją Iana.

Do realizacji zadania (drugi element triady funkcyjnej) lingwistKomplikacje ka wykorzystuje kolejne modele aktów komunikacyjnych: przedstawia się, obserwuje, próbuje zrozumieć przekaz ustny (dźwiękowy) oraz pisemny (znakowy), uczy się rozumieć strukturę języka pisanego (rzutowanego) przez Obcych. Uważny widz dostrzeże, iż wraz z coraz większym zaangażowaniem badaczki, jak również z pogłębiającym się jej rozumieniem Obcych i ich języka, powracają do niej wspomnienia zmarłej córki. Stają się też one coraz wyrazistsze, mniej subiektywnie motywowane. Nie pojawiają się w ramach snu czy halucynacji z przemęczenia, lecz powracają, niejako wiążąc się z tematem właśnie przez bohaterkę omawianym czy opracowywanym. Są też coraz dłuższe, spójniejsze. Dla widza ufnego będą to właśnie wspomnienia: dziecko wszak umarło w pierwszym akcie filmu. Widz sceptyczny zada sobie pytanie raczej o naturę tych wspomnień. Jak to możliwe, że łączą się tak zasadniczo z teraźniejszością działań postaci?

Najbardziej zastanawiające $\mathrm{z}$ nich ma miejsce, gdy Louise podpowiada córce sformułowanie $\mathrm{z}$ asortymentu nauk ścisłych: „równanie

[8] Por. T. Goban-Klas, Media i komunikowanie masowe. Teorie i analizy prasy, radia, telewizji i Internetu, Warszawa, Kraków 2002, s. 42.
[9] S. Sontag, The imagination of disaster, [w:] eadem, Against Interpretation and Other Essays, New York 1965, s. 209-225. Wydanie polskie: S. Sontag, Katastrofa w wyobrażeniu, przeł. A. Skucińska, [w:] eadem, Przeciw interpretacji i inne eseje, Kraków 2011. 
o sumie niezerowej”, o które - jak twierdzi - powinna raczej zapytać swojego ojca. O mężczyźnie była mowa dotychczas tylko raz, także we wspomnieniu. Gdy dziecko było małe, matka zapewniała ją, że rozstanie rodziców nie znaczy, iż mniej ją kochają. Tym razem zaś, w zależności podkreślanej ostrym montażem pomiędzy teraźniejszością (Obcy) a przeszłością (córka), to specjalista fizyk Ian Donnelly wypowiada znamienne słowa, które Louise „przekazuje poprzez czas” własnemu dziecku. Niepokój, a może tylko ekscytujące zastanowienie, wzbudzają dwie korelacje: czasowa oraz personalna. Pierwsza każe zastanowić się, jaki jest wpływ przeszłości na teraźniejszość, a zwłaszcza: czy naprawdę tak właśnie należałoby te czasowe warstwy nazywać? Druga odnosi się do Iana i jego miejsca $\mathrm{w}$ fabule. Na pewno nie znali się z Louise przed misją związaną z Obcymi. Jakie wobec tego znaczenie ma mieć umieszczenie go w figurze ojca? Bo fakt, że tych dwoje lubi się, podziwia i dobrze ze sobą współpracuje, nie budzi wątpliwości. Romans jest więc jak najbardziej możliwy. Czy jednak on dopiero nastąpi, czy już miał miejsce? Tego typu sugestie i idące za nimi „sceptyczne” pytania wstrząsają strukturą fabularną i narracyjną. Odtworzenie pierwszej staje się problematyczne ze względu na niejasność ciągłości chronologicznej, zaś druga odsłania nieoczekiwanie niski poziom własnej komunikatywności[10].

Początek od nowa

Gdyby uznać, że cały pierwszy akt nie jest retrospektywny, lecz wyobrażony lub prospektywny (dotyczący przyszłości) w stosunku do głównej akcji filmu, musielibyśmy inaczej opisać jego funkcjonalność. W przypadku wyobrażonego dziecka inne staje się znaczenie początku filmu dla prezentacji postaci kobiety: nie tyle załamanej utratą, ile potencjalnie tęskniącej za macierzyństwem. To zaś zmienia ontologię obrazu w tym akcie, czyniąc go subiektywną projekcją Louise. Wciąż jednak niejasne pozostaje, dlaczego ta tęsknota obrazuje śmierć Hannah. Jeśli zaś wprowadzenie ma wymiar futurospekcji, historia przybycia Obcych staje się dla widza nie tylko próbą rozwiązania ich zagadki, ale także - na poziomie narracji - opowieścią o tym, w jaki sposób przyszłość (córka) łączy się z teraźniejszością (Obcy) i jaki mają na siebie wpływ te dwa poziomy czasowe. Każde najmniejsze wspomnienie dziecka nie będzie zatem de facto wspomnieniem, lecz antycypacją lub lepiej: rozpoznaniem przyszłości. W ten sposób obok pierwszej triady funkcyjnej w strukturze fabularnej pojawia się druga, a jej celem jest odkrycie zależności między tym, co reprezentują heptapody, a nieustannym myśleniem głównej bohaterki o córce.

Podczas uważnej (być może ponownej) projekcji filmu widz uzbrojony w tę wiedzę dostrzeże elementy potwierdzające tę zależność.

[10] Komunikatywność (wysoka/niska) jest jednym $\mathrm{z}$ podstawowych wymiarów narracji w dziele filmowym i wiąże się z tym, jak często i chętnie udzielane są wyczerpujące informacje na temat świata przed- stawionego, które z kolei prowadzą do zrozumienia dzieła przez widza. Por. D. Bordwell, Narration in the Film Fiction, Wisconsin 1985, s. 59. 
Kiedy bowiem konkretnie Louise ma wizje Hannah? Zawsze wówczas, gdy zgłębia język Obcych. Im bardziej się do nich zbliża, tym bardziej objawia jej się dziecko: czy to we śnie, czy w halucynacji, w dłuższych, czy krótszych momentach. A zatem działania zmierzające do realizacji obu triad funkcyjnych są tożsame: w obu przypadkach wiążą się z poznawaniem Obcych. Z czasem wizje przyszłości bohaterki będą - jak powiedziano - coraz pełniejsze i spójniejsze. Także rola Iana w tym układzie zacznie nabierać sensu. Ich relacja od początku ma znamiona wątku melodramatycznego[11]. Poznają się, są zafascynowani sobą, deklarują wzajemny podziw i sympatię. W ukradkowych spojrzeniach widać jeszcze więcej. Zaraz po przybyciu do bazy, gdy oboje wypełniają formularze medyczne i lekarz wojskowy pyta Louise o ciążę, zanim ona odpowie przecząco, spojrzy wymownie na Iana. On spojrzenia co prawda nie odwzajemnia, bo zajęty jest wspomnianymi papierami. Lecz to Louise przecież od początku ogniskuje wokół siebie narrację, więc jej spojrzenie ma większe znaczenia.

Na tym już etapie można by słusznie zastanowić się, czy nie mamy po prostu do czynienia z kłamstwem narracyjnym. Według Jacka Ostaszewskiego ma ono polegać na naruszeniu wiarygodności w przedstawianiu zdarzeń przez narratora, takim posługiwaniu się konwencjami przedstawiania (np. gatunkowymi), które łamią przyzwyczajenia odbiorcze, a wreszcie służyć ma dezorientacji widza, uniemożliwiającej mu zrekonstruowanie spójnej i sensownej historii (fabuły)[12]. Poprzez opis i analizę ostatnich scen filmu spróbuję rozwiać tę niepewność.

Ostatni akt jest dużo dłuższy niż zaledwie kilkuminutowe wprowadzenie, a rozpoczyna się od bezpośredniego kontaktu Louise z heptapodami. Zaproszona do ich przestrzeni, niemal fizycznie "dotyka” pisma, które tak wytrwale studiowała. Odczytuje znaki przekazane przez Obcych i sama kształtuje z nich swoje odpowiedzi. Zanurza się zatem ostatecznie w tym języku, nie próbując go przełożyć na żaden język ludzki. Tym samym, podążając w myśl klasycznej hipotezy Sapira-Whorfa (o której zresztą bohaterowie filmu rozmawiają), zmienia się jej myślenie[13]. Odkrywa przy tym, że językowa pisemna reprezenta-

[11] Dawid Bordwell twierdzi, że w kinie głównego nurtu - a trudno gatunkowy hollywoodzki Arrival uznać za przedstawiciela innego typu - wątek miłosny jest zawsze obecny, często pozostając na drugim planie dla głównego, związanego $\mathrm{z}$ wymogami gatunkowymi: D. Bordwell, op.cit., s. 157-158. W przypadku science fiction tym głównym będzie często potrzeba naukowego rozwikłania zagadki lub rozwiązanie problemu Obcych (czy to inwazji, czy obecności, czy potrzeby porozumienia). Tylko melodramat stawia wątek romansowy na pierwszym planie. Por. J. Ostaszewski, Historia narracji filmowej, Kraków 2018, s. $106-108$.

\section{Zakończenie}

[12] J. Ostaszewski, Podejrzani Briana Singera..., s. $37-38$.

[13] „Struktury językowe warunkują postrzeganie, klasyfikowanie, sposoby ujmowania rzeczywistości przez człowieka, wpływają na jego stan świadomości i cechy myślenia o rzeczywistości. W konsekwencji w samym języku zawiera się do pewnego stopnia obraz świata": A. Klimczuk, Hipoteza Sapira-Whorfa-przegląd argumentów zwolenników i przeciwników, „Kultura - Społeczeństwo - Edukacja” 2013, nr 1, s. 166. 
cja tego myślenia oddaje zdolność do traktowania czasu nielinearnie, niechronologicznie, lecz jako jednoczesność. Bohaterka pojmuje, iż dziecko, które jej się jawiło, jest (będzie) jej własnym dzieckiem, że od dłuższego czasu ulegała „inwazji wspomnień, które okazują się reminiscencjami nie przeszłości, lecz przyszłości”[14]. Za chwilę, podczas rozmowy z Ianem, zobaczy, że on jest ojcem tego dziecka. Wreszcie zrozumie, że zna język Obcych na tyle, by napisać o nim książkę. W zasadzie już ją napisała. Zna nie tylko ten język, ale i przyszłość. Zrealizowała cel określony w pierwszej triadzie funkcyjnej, heptapody bowiem przybyły na Ziemię właśnie po to, by przekazać ludziom te umiejętności. One zaś pomogą bohaterce - albo pomogły - uratować świat, co jest z kolei realizacją celu wyznaczonego gatunkiem filmu.

W jednej z ostatnich scen, na przyjęciu u prezydenta Stanów Zjednoczonych, Louise spotyka przywódcę chińskich sił zbrojnych generała Shanga (Tzi Ma), który chciał zniszczyć Obcych. On dziękuje jej za telefon, który wykonała, by go przed tym powstrzymać. Pokazuje jej ten numer telefonu i mówi (przypomina/zapowiada), co mu powie(działa) „niegdyś” do niego dzwoniąc: wypowiedziała ostatnie słowa jego zmarłej żony, które teraz on jej zdradza. Louise jest zaskoczona, lecz przecież to jest jej przeszłość, a właściwie teraźniejszość, która ma mieć miejsce w przyszłości... Jak przybycie Obcych, jak tajemniczy język heptapodów, jak miłość Iana, jak Hannah, ich dziecko... [15]. Cel drugiej triady funkcyjnej: odkrycie zależności między poziomami czasowymi, a zarazem córką i Obcymi, został tym samym wyjaśniony. Powraca pytanie: czy tak skonstruowany sposób opowiadania ma znamiona kłamstwa narracyjnego?

Czy rekonstrukcja przebiegu fabularnego jest możliwa i zachowuje spójność? Wydaje się, że nie tylko tak jest, ale w sytuacji mocy bohaterki i jej panowania nad czasem narracja zostaje jej podporządkowana ostatecznie. Jest to zatem faktyczna, acz zarazem trochę paradoksalna subiektywizacja wszechwiedząca. Nawet widz sceptyczny pozostaje bezradny wobec wnioskowanych rozwiązań. Jak bowiem odkryć czas narracji takiej subiektywnej instancji? Należałoby go zrównać z czasem fabularnych. Jak dla bohaterki, tak dla narracji czas jest zawsze teraźniejszy. A jako że Louise poznaje swoją władzę nad czasem na oczach widza, nie sposób uznać jej nawet za narratorkę niewiarygodną. Owszem, pierwszy akt filmu był prezentowany w konwencji wspomnienia, a nie futurospekcji, widz został więc wprowadzony w błąd. Jednocześnie przyjąć należy, że dzieło filmowe rozgrywa się w czasie linearnym i w takim samym funkcjonuje jego odbiorca. To właśnie ograniczenie możliwości widza sprawiło, że został zwiedziony[16].

[14] B. Szczekała, Mind-game films. Gry z narracja i widzem, Łódź 2018, s. 87.

[15] Barbara Szczekała nazywa te zabiegi narracjami retroaktywnymi i rozpoznaje w nich - za Thomasem Elsaesserem - wsteczną przyczynowość, czy też odwrócony czas w przyczynowości. Por. ibidem, s. $85-91$.
[16] Więcej o narratorze niewiarygodnym por. J. Ostaszewski, Narrator niewiarygodny w filmie fabularnym, „Kwartalnik Filmowy” 2010, nr 71-72, s. $60-74$. 
Zamiast narratora niewiarygodnego, czy nawet kłamstwa narracyjnego, mamy raczej do czynienia $z$ narracyjną prawdą ogólną[17]. Wszystko, co przedstawia Louise, jest faktem, bo Louise wszystko wie. W połączeniu z subiektywizacją wszechwiedzącą bohaterki-narratorki można uznać, że każde z ogniskowanych wokół niej wydarzeń jest realne (w swojej fikcjonalności). Tragizm ich niezaprzeczalności tkwi z tym, że bohaterka-narratorka pozostaje człowiekiem. Jej umiejętności, owszem, uratowały świat, zyskała szacunek przywódców największych imperiów, posiadła pozaludzkie zdolności językowe i zna przyszłość, lecz musi też ponosić konsekwencje tych zdolności.

Pierwszą i podstawową konsekwencją jest wiedza o śmierci własnego dziecka. Louise, znając ten fakt, decyduje się nie tylko urodzić, ale spłodzić Hannah. Mówi, że czerpie radość z każdej chwili jej życia. Jej postawa jest zaskakująca, zdaje się nieludzko okrutna. W jednej z finałowych scen, już po bezpośredniej nauce języka heptapodów kobieta tłumaczy córce, dlaczego jej ojciec od nich odszedł. „Powiedział, że podjęłam złą decyzję" - mówi. Tą decyzją jest właśnie dziecko. Louise musiała zdradzić mężczyźnie tajemnicę, na którą on nie był gotowy: że Hannah umrze. Morał wydaje się kształtować następujący: tylko wiedza o przyszłości pozwala bohaterce w pełni cieszyć się z teraźniejszości. Jako że jest ona narratorką, demonstratorem obrazów, demiurgiem świata przedstawionego, jej wiedza wykracza daleko poza wiedzę przeciętnego człowieka, musi też nieprzeciętnie decydować i reagować na własną rzeczywistość.

Taki układ narracji ma też konsekwencje dla niej samej. Była już mowa o czasie narracji tożsamym z czasem fabularnym, przy czym oba dzieją się w nieustającej teraźniejszości. Film zatem, obok tematu gatunkowego (przybycie Obcych i poznanie ich języka), drugoplanowego (miłość: zarówno dwojga ludzi do siebie, ale przede wszystkim miłość macierzyńska) oraz pobocznych (społecznego, politycznego, technicznego), podejmuje i rozważa motyw czasu. Jest jednak nie tyle narracją o czasie, co raczej n a r r a cją c za s e m. Czas jest tu przecież bohaterem przejrzanym i okiełznanym. Jest wrogiem, którego można pokonać i nad którym można zapanować dzięki zgłębieniu języka heptapodów. Zarazem, jak słusznie pisze Barbara Szczekała w swojej błyskotliwej analizie filmu Arrival, „dzięki pośrednictwu Louise także widzowie znajdują się w pętli czasu, którego symulowane doświadczenie ucieleśniają. [...] Mamy okazję inaczej odczuć czas, gdyż - między innymi za pomocą narracji i fokalizacji - znajdujemy się w środku fikcyjnego świata możliwego o zupełnie innej czasowości”[18]. Obcy

[17] Prawda ogólna może być narzędziem kłamstwa i kłamania, lecz tylko w autentycznej sytuacji komunikacyjnej a nie w fikcji, która tę sytuację określa, bardzo jasno zrównując wiedzę nadawcy i odbiorcy na temat prawdziwości wydarzeń świata fikcyjnego

\section{Wnioski i morały}

(faktów fikcjonalnych). Por. J. Antas, O kłamstwie i kłamaniu. Studium semantyczno-pragmatyczne, Kraków 200o, s. 23-72, 148-150.

[18] B. Szczekała, op.cit., s. 89. 
przywieźli Ziemianom broń przeciwko czasowi rozumianemu jako upływ, a ostatecznie - dla każdego życia - kres. Brzmi to przerażająco, gdy uznać życie za największą wartość, a to przecież pozostaje najbardziej humanistyczną (czyt. ludzką) myślą. Narracja czasem oznacza zatem władanie nim. Dla Louise to zrozumienie, że należy i można mu się poddać. Jeśli czas działa, to narracja czasem działa ponad nim. Kres zaś przestaje być grozą w okolicznościach zgody na nieustającą teraźniejszość i wszechwiedzę.

Epilog, czyli adaptacja
W zasadzie mogłoby to stanowić zakończenie rozważań o strukturze narracyjnej filmu Arrival, lecz powrócę do ich początku i wspomnianej kategorii widza metaświadomego, który jest odbiorcą filmowej adaptacji znanego sobie literackiego pierwowzoru. Nie wykorzystałem go w toku analizy, gdyż opowiadanie Teda Chianga stanowi w zasadzie odpowiedź na wszystkie filmowe zagadki narracji, czasu, postawy humanistycznej wobec życia. Realizuje je tyleż eksplicytnie, co w sposobie prezentacji dwóch głównych tematów: opowieści o życiu córki, kierowanej do niej samej (w literaturze Hannah zginęła podczas wspinaczki górskiej w wieku 25 lat) oraz próby odkrycia tajników języka heptapodów (tłumacz opowiadania nazywa je siedmionogami). Pierwsza warstwa fabularna jest opowiadana niechronologicznie: na początku dowiadujemy się o śmierci dziewczyny, a na końcu o pragnieniu spłodzenia jej. Także językowo cała ta opowieść realizuje się przy wykorzystaniu czasu przyszłego w konwencjonalnej funkcji przeszłego, a do tego w niestandardowej drugiej osobie liczby pojedynczej. Narratorką jest oczywiście Louise, która opowiada (o) córce: „powiesz, odezwiesz się, będziesz się bawiła" itd. Wyrazista narracja (i zabawa) czasem, ustalająca pozorną kolejność wydarzeń, unaocznia się w krótkiej relacji, wyrażonej dwoma następującymi zdaniami: „Telefon z prośbą o to spotkanie b ył zapewne drugim $\mathrm{z}$ najważniejszych w moim życiu. Najważniejszy b ę d z i e rzecz jasna ten z Górskiego Pogotowia Ratunkowego"[19]. Narratorka zdaje się być w teraźniejszości. Jej przeszłość to wydarzenia związane z przyjazdem Obcych (telefon wzywający ją do pracy nad ich językiem), a jej przyszłość to życie i śmierć dziecka. Wie ona jednak o tej przyszłości tak dużo, że w zasadzie jest poza nią lub też „wybiera” pozycję czasu narracji, sytuując się pomiędzy dwoma wymiarami fabularnymi. Lecz i te wymiary ułożone w schemat stają się dwuznaczne, niejasne jest ich miejsce w fabule. Ta wszak zależy od chronologii. Dopóki zaś nie możemy z całą pewnością stwierdzić następczości wydarzeń, pozostaje nam uznać, że dominantą jest także w opowiadaniu n ar r a cja c z a s em.

Również w kwestii znaczenia języka heptapodów dla opanowania czasu znajdujemy eksplicytne wyjaśnienia:

[19] T. Chiang, Historia twojego życia, tłum. M. Jakuszewski, [w:] idem, Historia twojego życia, tłum. zbiorowe, Warszawa 2016, s. 135. Wyróżn. - A.M. 
U ludzi rozwinęła się świadomość sekwencyjna, natomiast u siedmionogów jednoczesna. My doświadczaliśmy wydarzeń po kolei i postrzegaliśmy związki między nimi w kategoriach przyczyny i skutku, one zaś doświadczały wszystkich wydarzeń jednocześnie i dostrzegały kryjący się za nimi $\operatorname{cel}[20]$.

Gdyby więc posłużyć się wiedzą z literackiego pierwowzoru do analizy narracji filmowej, utracilibyśmy nie tylko widza naiwnego, ale nie można by uruchomić pracy analitycznej widza sceptycznego. Świadomość (wiedza) w tym wypadku zubaża proces poznawania, dając gotowe odpowiedzi. Dlatego właśnie nazwałem znawcę problematyki omówionej w opowiadaniu w kontekście lektury jego dość wiernej adaptacji filmowej - widzem metaświadomym.

$\mathrm{Na}$ ostatnim, powiedzmy: ludzkim poziomie bohaterka-narratorka wyraża przekonanie: „teraz, kiedy już znam przyszłość, nigdy nie uczynię niczego, co byłoby z nią sprzeczne, a również nie zdradzę nikomu tego, co wiem" [21]. Zaraz też tłumaczy, co wynika dla niej z tej wiedzy, powołując się na poznany właśnie język siedmionogów, a zarazem jego filozofię:

Dla siedmionogów wszystko, co mówią, ma charakter performatywny. Język nie służy im do przekazywania informacji, lecz do urzeczywistniania. Faktycznie wiedziały, co będzie powiedziane w każdej rozmowie, którą kiedykolwiek przeprowadzą, lecz by ich wiedza okazała się prawdziwa, rozmowa musi się odbyć[22].

Warto po raz kolejny zwrócić uwagę na użycie w jednym wywodzie logicznym trzech różnych czasów: przeszłego („wiedziały”), przyszłego („przeprowadzą”) oraz teraźniejszego („mówią”, „służy”, „musi”). W normalnych okolicznościach łatwo zakwestionować poprawność takiej wypowiedzi, podważyć jej logikę. Sztuka narracyjna jednakże - tak literatura, jak film - może znajdować sposoby na artystyczne opracowanie takiego opowiadania historii, by tę logikę uzasadnić. W przypadku rzeczonego dzieła tym sposobem jest właśnie narracja czasem.

Antas J., O kłamstwie i kłamaniu. Studium semantyczno-pragmatyczne, Kraków 2000

Bordwell D., Narration in the Film Fiction, Wisconsin 1985

Chiang T., Historia twojego życia, przekł. zbiorowy, Warszawa 2016

Culler J., Teoria literatury. Bardzo krótkie wprowadzenie, przeł. M. Bassaj, Warszawa 1998

Goban-Klas T., Media i komunikowanie masowe. Teorie i analizy prasy, radia, telewizji i Internetu, Warszawa, Kraków 2002

Helman A., Twórcza zdrada. Filmowe adaptacje literatury, Poznań 1998

Klimczuk A., Hipoteza Sapira-Whorfa - przeglad argumentów zwolenników i przeciwników, „Kultura - Społeczeństwo - Edukacja” 2013, nr 1, s. 165-181

[20] Ibidem, s. 187-19o.

[22] Ibidem, s. 194.

[21] Ibidem, s. 193. 
Ostaszewski J., Historia narracji filmowej, Kraków 2018

Ostaszewski J., Narrator niewiarygodny w filmie fabularnym, „Kwartalnik Filmowy” 2010, nr 71-72, s. 60-74

Ostaszewski J., Podejrzani Briana Singera. Przypadek kłamstwa narracyjnego, „Kwartalnik Filmowy” 2004, nr 46, s. 26-42

Plesnar Ł., Organizacja struktury fabularnej Obywatela Kane Orsona Wellesa, [w:] Analizy i interpretacje. Film zagraniczny, red. A. Helman, Katowice 1986, s. $44-57$

Sontag S., The imagination of disaster, [w:] S. Sontag, Against Interpretation and Other Essays, New York 1965, s. 209-225

Sontag S., Katastrofa w wyobrażeniu, przeł. A. Skucińska [w:] S. Sontag, Przeciw interpretacji i inne eseje, Kraków 2012, s. 279-301

Szczekała B., Mind-game films. Gry z narracją i widzem, Łódź 2018 